\title{
Biocarbon from bark or black pellets as an alternative for coal in steelmaking - techno-economic evaluation
}

\author{
Juha Hakala ${ }^{a}$, Petteri Kangas ${ }^{a \dagger}$, Lotta Rintala ${ }^{a}$, Timo Fabritius ${ }^{b}$, Pertti Koukkari ${ }^{a}$ \\ a VTT Technical Research Centre of Finland, P.O. Box 1000, FI-02044 VTT, Espoo, Finland. Contact Juha Hakala \\ juha.hakala@vtt.fi \\ b Process Metallurgy Research Unit, University of Oulu, P.O. Box 4300, FI-90014 University of Oulu, Oulu, Finland \\ ${ }^{\dagger}$ Deceased November $3^{\text {rd }}, 2019$
}

\section{Abstract}

In 2018, global crude steel production was approx. 1.8 gigatonnes while its direct $\mathrm{CO}_{2}$ emissions stood at 2 giga tonnes (2017), representing $23.5 \%$ of all direct industrial emissions. Globally iron and steel industry (ISI sector) is the second largest emitter after the cement industry while in Finland and Sweden the ISI sector is the largest industrial source of fossil $\mathrm{CO}_{2}$. Biocarbon received from forest sector residues, such as bark, sawdust and lignin, provides an opportunity to a rapid reduction in fossil $\mathrm{CO}_{2}$ emissions in the industry. Use of biocarbon for reduction purposes bestows an asset for both the forest and metals production and processing industry in Finland as well as in the Scandinavian countries. In this study, the focus was on the techno-economic evaluation of biocarbon production 1) from bark-based black pellets produced in a stand-alone plant close to a steel mill, and 2) from bark produced in a pulp mill integrated plant. The economics of biocarbon production costs from bark appear promising, providing also an ample source, at an annual potential of up to 95,000 tonnes of biocarbon from a single pulp mill.

\section{Keywords}

Slow pyrolysis, techno-economic evaluation, biocarbon, black pellets, bark, bio-reducer Highlights

- Bio-reductants can be used to decrease fossil $\mathrm{CO}_{2}$ emissions in the steel industry, enabling up to $95 \%$ reduction in $\mathrm{CO}_{2}$ equivalents for substituting fossil coal with the bio-reductant

- Biocarbon received from forest industry residues apply for reduction purposes

- Biocarbon can be an asset both for the forest and metal industry

- Integration of biocarbon production to a pulp mill provides economic benefits, possible reduction in production costs up to the level of $30 \%$

- Modern pulp mill could supply up to 95,000 tonnes of bark-based biocarbon annually

\section{Introduction}

The carbon dioxide emissions of Finnish Steel industry exceed 5 million tonnes annually, which is over $10 \%$ of the total $\mathrm{CO}_{2}$ release in Finland (Hakala et al., 2019). In Sweden, the $\mathrm{CO}_{2}$-equivalent emissions are ca. 6 million tonnes annually, which is more 
than one third of industry emissions in the country (Olofsson, 2019). Globally the $\mathrm{CO}_{2}$ emission are ca. 23\% of direct industrial emissions (Fernandez-Pales and Levi, 2019).

With the large volumes of both energy and reductants required and with the various options for carbon utilization in present day steel manufacturing (such as sintering, coke breeze, coal blending, injection and product recarburizing) it seems inevitable that in sustainable steel manufacturing bio-based carbon sources will offer a viable solution for mitigating the climate burden of the industry.

Most $\mathrm{CO}_{2}$ emissions in steel production occur during the reduction of iron ore to hot metal through the use of coal and coke. Carbon is needed both as an energy source but, more importantly, as a reducing agent. Renewable carbon containing material from the forest sector is seen as an asset for reducing fossil emissions from the steel industry (Wiklund, 2016; Suopajärvi, 2014; Olofsson, 2019). These bio-based carbon sources can be used as bio-reducing agents in the short term that provide a rapid reduction in fossil $\mathrm{CO}_{2}$ emissions. In the long term, new process concepts based on the use of renewables for energy and reduction (such as hydrogen reduction and/or the use of electricity in plasma technology) can be implemented (Suopajärvi et al., 2018; $\mathrm{Ng}$ et al., 2018; HYBRIT, 2019). The direct reduction of iron (DRI) ore with hydrogen on a large scale is under development (HYBRIT, 2019), and is aiming to replace coking coal - traditionally required for ore-based steelmaking - with hydrogen. This method emits water vapour instead of generating direct $\mathrm{CO}_{2}$ emissions. The goal is to have an industrial process in place by 2035 (Sherrard, 2019). There are also ambitious plans to convert blast furnaces in Sweden and Finland by 2045 (Bioenergy International, 2018). In addition, technologies relating to carbon capture and storage (CCS) are seen as potential solutions (Arasto, 2015) for reducing emissions from the steel industry, although the adaptation of these technologies will take quite some time. Furthermore, as carbon injection will be needed for both smelting and recarburizing, these long-term changes in operational practices, whether in terms of DRI, hydrogen reduction, plasma or CCS, are not likely to displace the use of considerable volumes of carbon as one salient component of steelmaking.

In Finland and Sweden, the key source for bio-based carbon is woody feedstock. If ISI sector will enter as a new user of this raw material it would affect the regional market and prices e.g. in the northern parts of both countries (Olofsson 2019). While the global market for Kraft pulp has also evolved favourably during the last decade, the demand of woody feedstock has respectively increased. However, the subsequent growing interest in wood harvesting has raised concerns on reduction of the forestbased carbon sink. Accordingly, the current side streams of the forest industry, such as bark, forest residues and sawdust, have been identified as a potential source of biocarbon. In Finland, roughly $50 \%$ of these side streams are needed for the internal energy production of the mills, and the other half could be utilized as products to support low carbon economy. Modern Kraft pulp mills use the side streams for producing excess heat and electricity, which are not utilized by the mills themselves.

The competition for the utilization of these bio-based residues is emerging, enhanced by the rising costs of emission trading in the form of the European Emission Allowances (EUA), which reached the price level of $€ 30 /$ tonne of $\mathrm{CO}_{2}$ equivalents in 
September 2020 (ICE, 2020). Potential new uses for residues include biofuels, biochemicals and materials. One of the attractive new options is biocarbon to be used in the metallurgical industry instead of fossil carbon or coke. As raw biomass per se is unsuitable for applications in reductive metallurgy, thermochemical conversion into biocarbon is required.

$\mathrm{Ng}$ et al. (2018) recently developed a techno-economic model to evaluate the so-called value in use (VIU) of the converted solid biocarbon in blast furnace ironmaking. This model calculates the hot metal production costs, including the cost of iron ore pellets, fluxing agents, coke, oxygen, blast delivery, pulverized coal for injection ( $\mathrm{PCl}$ coal) and $\mathrm{CO}_{2}$ emissions. The oxygen to carbon mass ratio $(\mathrm{O} / \mathrm{C})$ of the solid biocarbon, determined by the conversion technology applied, significantly influences the VIU value of solid biocarbon. According to $\mathrm{Ng}$ et al., production costs decrease as the $\mathrm{O} / \mathrm{C}$ mass ratio of biocarbon decreases.

Suopajärvi et al. (2017) provided an overview of the biomass-based reducing agent production costs for torrefied biomass, charcoal (or biocarbon), bio-synthetic natural gas (bio-SNG), bio-oil and bio-hydrogen in Europe, Australia and North America, capacities ranging from 50 to 5,000 dry tonnes per day. Most of the studies selected wood-based feedstock. The production costs, when compared on an energy basis, were lowest for torrefied biomass. Still, slow pyrolysis is the most promising technology for upgrading biomass into a solid metallurgical reducing agent (Suopajärvi et al., 2018). Slow pyrolysis produces biocarbon with high enough carbon to oxygen ratio and heating value, the properties thus being close to fossil coal. This enables the higher substitution of fossil coal with biocarbon in the reduction applications without major modification requirements for the existing processes. Torrefied biomass, for example, has lower carbon to oxygen ratio, remaining to the level comparable to biomass, as well as the heating value is relatively low, which may hinder it's use as substitute for injection coals and/or reducing agents.

The biomass volume is reduced during pyrolysis and biocarbon pellets are obtained for efficient storage and transportation, instead of storing and transporting large volumes of the moist biomaterial for example. The produced pellets are energy-intensive, dense and stabile. However, if the biocarbon pellets are intended to be used as a substitute for coke, biocarbon is still generally characterized by its lower density, mechanical strength and high reactivity. To overcome this, Riva et al. (2019) suggest biocarbon production methodology that consists of pyrolysis at $600{ }^{\circ} \mathrm{C}$, densification (using pyrolysis oil as a binder) and reheating of the obtained pellet.

In an integrated steel plant, biomass products can be used in (i) coke-making for production of bio-coke; (ii) sintering process for production of bio-sinter, (iii) pelletizing/briquetting for production of bio-composites and/or bio-briquettes, (iv) partial replacement of pulverized coal injected into a blast furnace and ( $v$ ) biorecarburization of steel in a ladle furnace. Of these, the replacement of coal injection has generally been accepted as the most technically straightforward and economically viable option (e.g. Ng et al., 2018; Suopajärvi et al., 2018; Mousa et al., 2016). Pulverized coal (or biocarbon) injected to the blast furnace is not only fuel but (together with coke) an important reducing agent for the reduction of the iron ore. 
Biocarbon could also replace the fossil coal injection in electric arc furnaces, as well as could be applied as carbon reductant in non-ferrous industry.

SSAB Brahestad Steelworks in Finland has carried out the successful 9 days full-scale tests to replace approximately $10 \mathrm{wt} \%$ of fossil $\mathrm{PCl}$ coal needed for the blast furnace process by biocarbon. Thus, according to SSAB, these tests show that at least $10 \mathrm{wt} \%$ of the $\mathrm{PCl}$ coal could currently be replaced by biocarbon. SSAB has also carried out their own laboratory tests showing that up to $20 \mathrm{wt} \%$ replacement ratio is possible with the current technical solutions. Thus, biocarbon utilization in $\mathrm{PCl}$ appears to be a potential way to reduce emissions from steel production. Biocarbon blend of $10 \mathrm{wt} \%$ would mean an annual reduction of 100,000 tonnes of the emitted fossil-based carbon dioxide. Currently, it is a challenge to find a biocarbon producer with a high enough production capacity (Bioenergy International, 2019; Ahonen, 2019).

Hakala et al. (2019) evaluated the effect on global warming potential when substituting $\mathrm{PCl}$ coal with the biocarbon. Even up to $95 \%$ reduction in $\mathrm{CO}_{2}$ equivalents is possible for the substituted portion of $\mathrm{PCl}$ coal. In this scenario, it is assumed that green electricity covers the decreased electricity generation in the pulp mill integrate, where the production of bark based biocarbon would also take place. If the lower electricity generation is compensated with the average Finnish grid electricity instead, the reduction potential is somewhat lower ( $86 \%$ in $\mathrm{CO}_{2}$ equivalents). The effect of the biocarbon production on electricity generation is further described in the Chapter 2.4.

The aim of this study was to evaluate the technical and economic feasibility of converting residual bark from a Kraft pulp mill into biocarbon to be used as a substitute for fossil $\mathrm{PCl}$ coal in steel production. Two technological options were assessed: i) production of biocarbon from bark-based black pellets in a stand-alone plant and ii) biocarbon produced directly from bark in an integrated Kraft pulp mill.

\section{Methods and materials}

\subsection{Methodology}

A concept level techno-economic assessment was conducted for evaluating the feasibility of biocarbon production by pyrolysis. The raw material analysed and tested in this study was black pellets made of bark.

Mass and energy balances were calculated using process simulation software, Balas (VTT, 2013) for evaluating the slow pyrolysis process and Wingems (Valmet, 2016) for conducting process integration studies for a Kraft pulp mill. Production costs were evaluated during the economic assessment. Key process parameters were obtained from the literature.

The analysis of the integration of biocarbon production with a Kraft pulp mill is based on the reference softwood Kraft pulp mill model. The model comprises a single-line market pulp mill with wood handling, continuous cooking, two-stage oxygen delignification, ECF bleaching (D0-EOP-D1-P), pulp drying, seven-stage evaporation with tall-oil recovery, recovery boiler, re-causticizing and condensing turbine. This reference mill, based on the Future Pulp Mill (FUPU) concept, has been described in detail by Kangas et al., (2014). The FUPU model was developed using the WinGEMS 5.3 
modelling tool (Valmet, 2016). Additional analyses, such as economics, were performed using Excel spreadsheets and HSC Chemistry 9 (Outotec, 2017) and e!Sankey (ifu Hamburg, 2015) was used to illustrate the relevant mass flows.

A sensitivity analysis was conducted based on stochastic simulation, using Monte Carlo Method. Simulation runs of 30,000 were conducted, in order to illustrate the effects of input parameter distribution on production costs. The analysis tool @Risk was used (Palisade Corp., 2015).

\subsection{Raw materials}

Surplus bark is available at modern pulp mills due to the internal energy-efficiency of the mills. Bark can also be obtained from sawmills. Approximately $10 \%$ of all roundwood delivered to a mill is bark (Kangas et al., 2014). In the Northern countries in particular, debarking takes place at the mill, whereas forest debarking is more common for mills in the Southern hemisphere (Kuparinen and Vakkilainen 2017). Bark is typically used as boiler fuel at pulp mills. In modern pulp mills, surplus bark may be converted by gasification into syngas for combustion in a lime kiln. The elemental analyses and moisture contents of different bark fuels (and wood fuel in general) can be found in Alakangas et al. (2016). Moisture content varies between 40-70 wt\% depending of the debarking type and handling (dry, wet compressed, or wet uncompressed). Typical lower heating values (LHV) on a dry basis used as a fuel are as follows: pine bark $20 \mathrm{MJ} / \mathrm{kg}$, spruce bark $18.6 \mathrm{MJ} / \mathrm{kg}$ and birch bark $22.7 \mathrm{MJ} / \mathrm{kg}$ (Alakangas et al., 2016).

Pellet fuels can be defined as biofuels made from compressed organic matter or from different biomass, such as virgin wood, industrial wood-based side streams and waste, agricultural residues, and energy crops. Heat-treated wood pellets are referred to as black pellets due to their appearance following thermal treatment. The advantages of black pellets include the opportunity for outdoor storage, efficient transportation, good grindability, low dust formation and improved calorific value. Black pellets are generally converted from biomass by thermochemical routes, such as torrefaction or steam explosion (SE). Steam explosion was first introduced and patented as a biomass pre-treatment process in 1926 (Mason et al., 1926).

The Sundsvall pilot of Valmet Oyj provided samples of SE black pellets (referred later as black pellets). Raw material bark (40 wt\% spruce bark and $60 \mathrm{wt} \%$ pine bark) was obtained from a pulp mill located in Central Sweden. The bark feed was treated with steam for $5 \mathrm{~min}$ at $190^{\circ} \mathrm{C}$ in a pilot reactor (Valmet, 2019), after which it was steam exploded to atmospheric pressure, dried and pelletized (Toloue Farrokh et al., 2019).

Pyrolysis experiments and analyses by Toloue Farrokh et al. (2019) were performed for the black pellets samples. The LHV on a dry basis was analysed as $19.7 \mathrm{MJ} / \mathrm{kg}$ and the higher heating value (HHV) as $20.8 \mathrm{MJ} / \mathrm{kg}$, respectively. The ash content (dry basis) was $4.6 \mathrm{wt} \%$ and the moisture content $10.4 \mathrm{wt} \%$. Elemental composition of black pellets without ash is given in moles in the Table 1.

Bark as such was evaluated as a raw material, too, since the conversion by pyrolysis can be done directly from bark, and thus the black pellets conversion process from 
bark would not be needed. In the case study, it was assumed that biocarbon samples from black pellets represent the thermal and chemical properties of biocarbon obtained directly from softwood bark. Thus, the dry composition without ash (elemental analysis) and the ash content of biocarbon made from softwood bark were assumed the same as those of biocarbon made from black pellets. A lower heating value as dry and elemental analysis of black pellets were also applied to bark. The dry content of bark was fixed at $40 \mathrm{wt} \%$. These assumptions also generally agree with the literature data on softwood bark (Alakangas et al., 2016).

Black pellets made of bark and thus also softwood bark were found to be applicable as a sources of metallurgical grade biocarbon. The alkali and phosphorus content of biocarbon originating from bark is acceptable if less than $20 \%$ of blast furnace $\mathrm{PCl}$ coal is replaced by this biocarbon, while higher fractions of bio-based $\mathrm{PCl}$ coal will require further technological assessment (Hakala et al., 2019; Toloue Farrokh et al., 2019; Suopajärvi et al., 2018). Too much of phosphorus entering the blast furnace degrades the steel quality and alkali fumes disturb the smelting process. Toloue Farrokh et al. (2019) give the detailed physico-chemical and rheological characterization of the said biocarbon samples.

\subsection{Processes}

There are two options for processing bark to biocarbon: i) Thermochemical conversion to black pellets and further slow pyrolysis of such pellets to biocarbon, or ii) slow pyrolysis of bark to biocarbon when the intermediate step of black pellets is omitted. Both options are potential scenarios depending also on whether the biocarbon processing is conducted integrated to a pulp mill or at a stand-alone plant located e.g. in the vicinity of a steel mill.

In slow pyrolysis the biomaterial is led through grinding and feeding to the pyrolysis unit at a moisture content of approx. $10 \mathrm{wt} \%$, gradually heating to $300-600{ }^{\circ} \mathrm{C}$ with a residence time from 15 minutes to several hours and takes place in the absence of air (Suopajärvi et al., 2018). In order to achieve this, many different types of industrial charcoal pyrolysis units are available. The charcoal kiln has conventionally been the most common type. Currently, the most popular unit is based on a retort design. The different names given to charcoal kilns or retorts are based on slight variations in design, although the principles of operation are similar (Tutturen 2013). The commercial processes typically operate near atmospheric pressure and most units use wood as the feedstock. The main principles of charcoal production include internal heating, external heating and heating of recirculated gas (Antal et al. 2003). Different pyrolysis processes are reviewed in detail in Hakala et al. (2019).

In this work, heat and mass balance scenarios were developed for a typical slow pyrolysis process without specification of the particular reactor. Low-grade heat (hot water and low pressure steam) is used for drying the feedstock and hot pyrolysis gases are assumed to be partially burned in order to provide the necessary heat for maintaining the pyrolysis reactions. Depending of the scenario, the remaining hot pyrolysis gases are further burned to provide heat for drying, to provide steam for the steam turbines, or used as a fuel gas to replace other fuels, for example, in the lime 
kiln at pulp mills. Biocarbon is cooled and pelletized for transportation and handling. The suitability of the technology for necessary upscaling and for meeting the charcoal quality requirements for replacing $\mathrm{PCl}$ coal needs to be verified.

\subsection{Process integration}

Biocarbon can be produced at a pulp mill or a pulp and paper mill using the side stream biomass available on site. In pulp mills, low-temperature excess heat (hot water) and excess steam is often available for drying biomass prior to pyrolysis. Hot pyrolysis gases can be used to replace other fuel uses, such as in a lime kiln, thereby releasing the original biofuels for other uses, or reducing the use of fossil fuels. The biomass volume is reduced during pyrolysis and biocarbon pellets are obtained for efficient storage and transportation, instead of storing and transporting large volumes of raw materials such as bark.

Utilizing low-temperature excess steam from a pulp mill has certain negative effects, as this steam would have been utilized in the steam turbines of the pulp mill's power plant. One of the topics of this study was to estimate this effect, by combining the losses caused in electricity production with the production costs of biocarbon. Within this study, the reference softwood Kraft pulp mill model (see Chapter 2.1) has been used for estimating the integration effects of biocarbon production on Kraft pulp mill energy balances. The market pulp mill is illustrated in a block flow diagram in Figure 1, giving the baseline for the pulp mill integrated bark scenario, visualizing also the pulp mill integrated bark scenario presented in the Chapters 2.5 and 3.2. The total bark yield is 600,000 tonnes per year with a dry content of $40 \mathrm{wt} \%$. Half of the bark is gasified and the lime kiln is fired with the resulting syngas. The remaining bark (50 wt\%) is combusted in a multi-fuel boiler. A significant amount of excess heat is produced, and a condensing turbine is used to convert the heat into electricity. The net electricity output is around 1,000 GWh per year. Lime kiln heat requirement is estimated to be ca. $570 \mathrm{GWh} / \mathrm{a}$, based on the value of $1.7 \mathrm{GJ} /$ tonne of pulp produced, derived from the softwood Kraft pulp mill model. Syngas may not be enough to cover all the heat, thus also applicable bio-oil is to be used as a fuel for the lime kiln, too. 


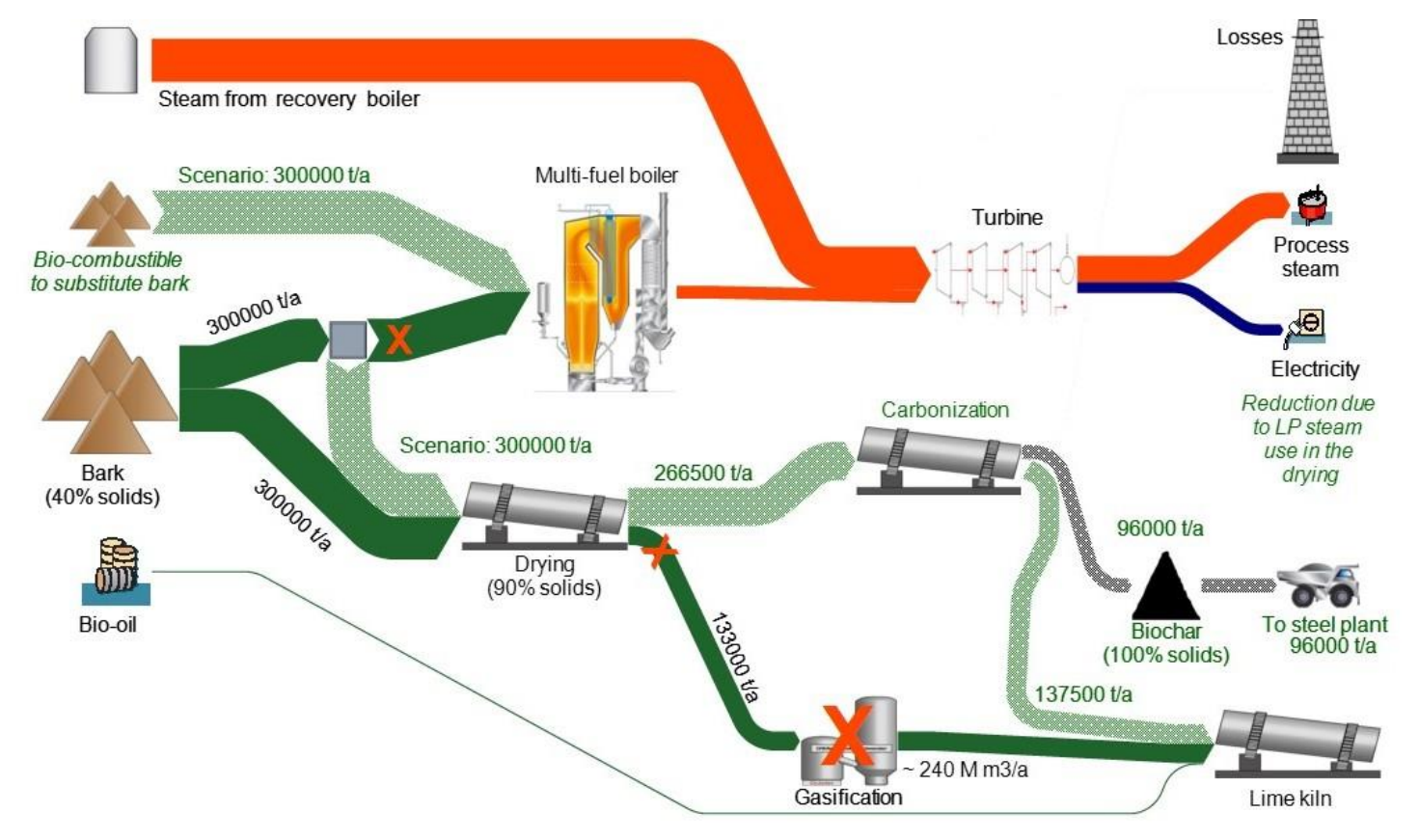

Figure 1. Reference Kraft pulp mill, producing 1.2 million air-dry tonne (adt) of softwood pulp, and the pulp mill integrated bark scenario for biocarbon production. Reference Kraft pulp mill is visualized as dark green streams. The pulp mill integrated bark scenario is visualized as lighter green dotted streams, and the related values and processes in green colour. The processes and the streams not existing in the scenario are marked with the red $X$.

\subsection{Scenarios}

The evaluated scenarios are: 1) biocarbon from black pellets produced in a stand-alone plant and 2) biocarbon from bark produced in an integrated Kraft pulp mill.

Stand-alone production (1) refers to the selected scenario in which the biocarbon pyrolysis unit is located on the site of a steel/iron plant and the raw material (black pellets) is transported by rail to the production site from a location within $275 \mathrm{~km}$. The biocarbon manufacturing process is not integrated with the steel plant itself, although the produced biocarbon is used on site to replace part of the $\mathrm{PCl}$ coal injected into the blast furnace. In practise, no further drying of black pellets is needed prior pyrolysis. The pyrolysis gases are burned in order to provide steam. The effect of surplus steam is evaluated by setting the electricity generation yield to $35 \%$ of the available heat load. The power plant itself is not included in the estimated scenario. This scenario is later referred as stand-alone black pellets scenario.

Pulp mill integrated biocarbon production (2) refers to a scenario in which biocarbon production takes place at a pulp mill, utilizing integration opportunities. This scenario applies to bark utilization as a raw material, available on site at the pulp mill (e.g. modern Nordic Kraft pulp mills located in Eastern Finland). Instead of gasifying 50 wt\% of bark input and burning the other half in a multi-fuel boiler, biocarbon and pyrolysis gases are produced from all bark input. It is assumed that the reduction of bark 
amount as a combustible may be compensated for using additional biofuels within the boiler, if required. The bark is first dried to a $10 \mathrm{wt} \%$ moisture content and then carbonized/pyrolyzed. Bark drying utilizes hot water and steam, each meeting $50 \%$ of the necessary heat load. It is assumed that the pulp mill can provide the hot water and steam. The pyrolysis gases (net) are redirected for further use as a fuel for the lime kiln at the pulp mill, replacing the gasified bark used in the baseline scenario. To cover endothermic reactions during pyrolysis, some of the generated pyrolysis gases are burned to provide the necessary heat load. From these flue gases some steam is generated for drying, reducing the need for steam from the pulp mill. No excess steam is available. The biocarbon product is then transported by rail to the iron/steel plant. This scenario is later referred as pulp mill integrated bark scenario.

Pulp mill integrated bark scenario (2) is based on assumption that samples from black pellets represent the thermal and chemical properties of biocarbon obtained directly from softwood bark. Additionally, biocarbon yield from bark was estimated to be slightly lower than the analysed yield from black pellets. Thus, the scenario 2 ) is more theoretical, providing the insight for direct bark utilization in pyrolysis.

\subsection{Process modelling and assumptions}

In the model that provides the data for the stand-alone production scenario (1), the pyrolysis and burning of pyrolysis gases are modelled within a combined isothermal reactor unit. Thus, no pyrolysis gases are obtained as side products. The simulation then calculates the exothermic energy from this combined reactor unit, while the pyrolysis itself is endothermic. A schematic diagram of the respective stand-alone setup is given in Figure 2. Heat is recovered from the flue gases in the boiler section of the model. The flue gas exhaust temperature is set at $130^{\circ} \mathrm{C}$. Steam generated in the model, from the boiler section and the combined reactor unit, is set to 2 bar (a). The energy requirement for drying and heat losses (drying, pyrolysis and boiler section) are estimated. The same amount of steam is condensed in the model's steam network. The excess steam is valued as producing electricity by configuring the electricity generation yield as $35 \%$ of the available thermal load. The low steam temperature for the calculation is not critical, since the overall thermal load is not sensitive with regards to the selected modelling temperature. The real steam pressure, which can be generated by burning the pyrolysis gases, will gain a much higher temperature, still comprising the same heat load as in the model, and is further assumed to be sufficient for the steam turbines at the power plant.

In the model that provides the data for the pulp mill integrated production scenario (2), presented in Figure 3, pyrolysis is calculated separately in an isothermal reactor unit. Thus, the model allows the use of pyrolysis gases for further utilization as a separate fuel, in this case, in the lime kiln. Part of the pyrolysis gases are combusted in the burner unit to provide the energy required for the endothermic reactions of the pyrolysis itself. Heat is recovered as steam ( 2 bar) from the resulting flue gases. The model also calculates the additional energy requirement for drying, which is provided from the pulp mill in the form of hot water and steam. No excess energy/steam is available. 
These two models provide data for the mass and energy balances and production costs calculations for the respective scenarios.

$\mathrm{PCl}$ coal feed is around $220 \mathrm{~kg}$ per tonne of hot metal produced. In this study it is estimated that approximately $22 \mathrm{~kg}$ of this fossil $\mathrm{PCl}$ coal feed can be directly replaced by biocarbon. The exact replacement ratio of $\mathrm{PCl}$ coal by biocarbon in the calculations is $9.8 \%$. The annual $\mathrm{PCl}$ coal total feed for two blast furnaces is fixed to the level of 450,000 tonnes, corresponding to the annual production of 2,045 $\mathrm{k}$ tonnes of hot metal. Thus, the amount of biocarbon applied at the annual level is 44,200 tonnes (Table 3). This amount is applied to the stand-alone black pellets scenario (1). However, for the pulp mill integrated bark scenario (2) the capacity is set according to the amount of bark assumed to be available at the pulp mill, leading to more than twice the amount of biocarbon than in the stand-alone black pellets scenario.

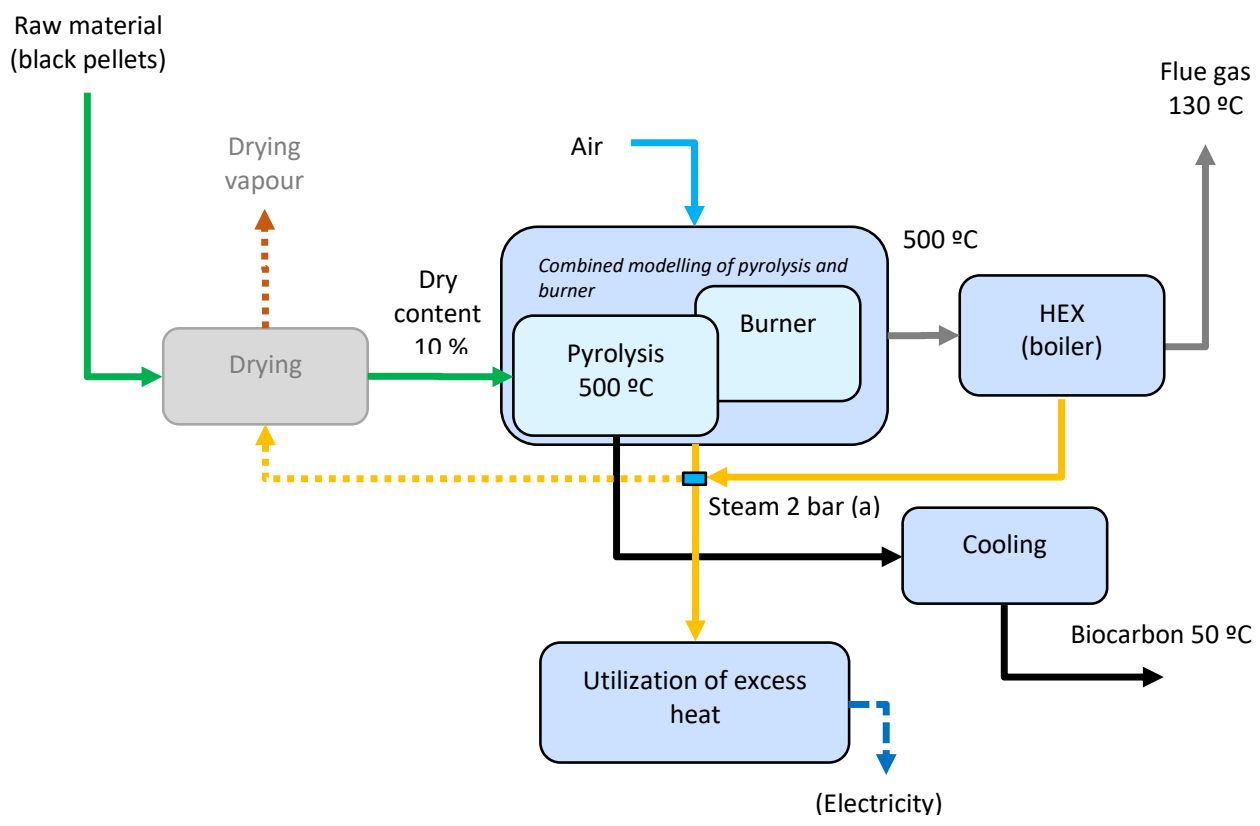

Figure 2. Schematic process diagram of the Balas simulation model providing data for the stand-alone production scenario. 


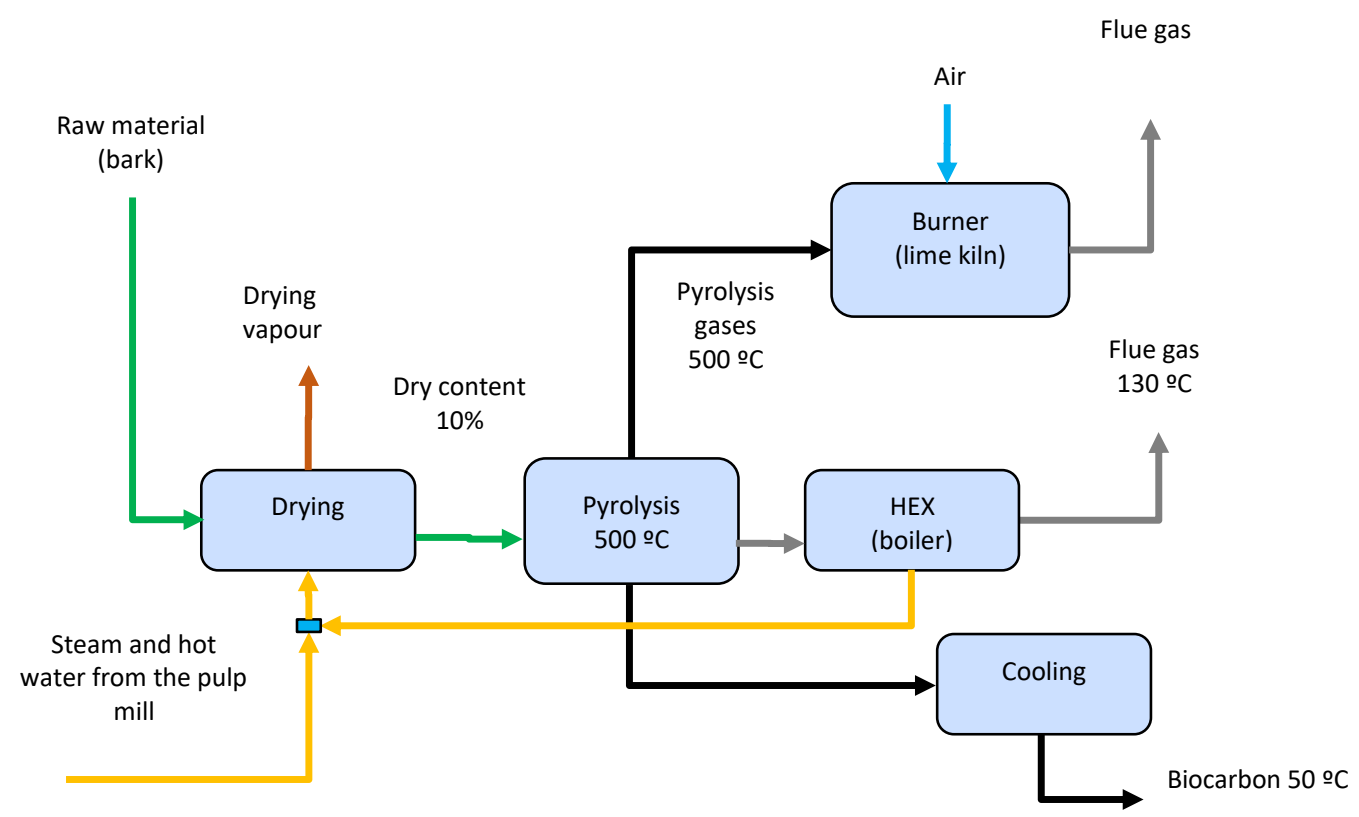

Figure 3. Schematic process diagram of the Balas simulation model providing data for the pulp mill integrated production scenario.

Table 1 presents the elemental compositions of the different modelling components applied without ash. Ash is treated separately as an inert component. Ash entering the pyrolysis ends up in the biocarbon.

In the pulp mill integrated bark scenario, the hot pyrolysis gases product is expressed by an artificial model component, which is created by deducting biocarbon from the pyrolysis feed material at the elemental level. The resulting elemental composition of this pyrolysis gas model component is presented in Table 1. The actual pyrolysis gases were not analysed within this study. For the pyrolysis gas component HHV is estimated by applying the element-based weight factors introduced by Channiwala and Parikh (2002), presented in Table 2. The resulting HHV value estimation for the bark pyrolysis gas is $15.46 \mathrm{MJ} / \mathrm{kg}$. It should be noted that the elemental weight percentage is outside the upper bound for oxygen, which may cause some error. Maximum introduced share for oxygen is $50 \mathrm{wt} \%$, while the model value is $56.5 \mathrm{wt} \%$. If the oxygen share would have been $50 \mathrm{wt} \%$, this would have meant the reduction of $4 \%$ in the heating value, giving an indication of the possible error.

Table 1. Elemental compositions of the different modelling components applied without ash. Molar compositions are scaled to $1,000 \mathrm{~g}$.

\begin{tabular}{rccccc}
\hline Modelling component & $\begin{array}{c}\text { C } \\
\text { [mole] }\end{array}$ & $\begin{array}{c}\text { H } \\
\text { [mole] }\end{array}$ & $\begin{array}{c}\text { N } \\
\text { [mole] }\end{array}$ & $\begin{array}{c}\text { O } \\
\text { [mole] }\end{array}$ & $\begin{array}{c}\text { S } \\
\text { [mole] }\end{array}$ \\
\hline Black pellet & 46.23 & 57.17 & 0.31 & 23.90 & 0.01 \\
Bark & \multicolumn{5}{c}{ As black pellets } \\
Black pellet biocarbon & 73.60 & \multicolumn{5}{c}{$30.01 \quad 0.82$} & 4.62 & 0.01 \\
Bark biocarbon & \multicolumn{5}{c}{ As black pellets biocarbon } \\
Bark pyrolysis gas & 30.06 & 73.21 & 0.02 & 35.29 & 0.01 \\
\hline
\end{tabular}


Table 2. Estimation of HHV value for bark pyrolysis gas by applying weight factors for each element as presented by Channiwala and Parikh (2002).

\begin{tabular}{rcccccc}
\hline & C & H & N & O & S & SUM \\
\hline Bark pyrolysis gas composition [wt\%] & 36.1 & 7.4 & 0.0 & 56.5 & 0.0 & 100 \\
Introduced min value for elements [wt\%] & 0.00 & 0.43 & 0.00 & 0.00 & 0.00 & \\
Introduced max value for elements [wt\%] & 92.25 & 25.15 & 5.60 & 50.00 & 94.08 & \\
Introduced weight factors for elements & 0.3491 & 1.1783 & -0.0151 & -0.1034 & 0.1005 & \\
The resulting bark pyrolysis gas HHV [MJ/kg] & 12.60 & 8.70 & 0.00 & -5.84 & 0.00 & 15.46 \\
\hline
\end{tabular}

The calculated and applied feed stream compositions and fixed mass-based stoichiometry for the reactions, set to meet molar balances of the elements, as well as the parameters, and their sources, applied to the modelling for both of the scenarios, are presented in Table 3. Column Bark (Ba) refers to the pulp mill integrated bark scenario (2) and Black pellets (BP) to the stand-alone black pellets scenario (1). The biocarbon yield for bark was estimated to be approx. $40 \mathrm{wt} \%$, being slightly lower than the analysed yield for black pellets. 
Table 3. Parameters applied in modelling the scenarios.

\begin{tabular}{|c|c|c|c|c|}
\hline & Unit & All & $\begin{array}{l}\text { Black } \\
\text { pellets } \\
(\mathrm{BP})(1)\end{array}$ & $\begin{array}{l}\text { Bark } \\
\text { (Ba) (2) }\end{array}$ \\
\hline Biocarbon production (amount for injection) ${ }^{d}$ & [k tonnes/a] & & 44.2 & 96.0 \\
\hline Yield of biocarbon, dry-based & [wt\%] & & 42.6 & $\left.40.0^{*}\right)$ \\
\hline Process in operation e & [h] & 8000 & & \\
\hline Raw material dry content as received ${ }^{a}$ & [wt\%] & & 89.6 & $\left.40.0^{*}\right)$ \\
\hline Dry content before pyrolysis (after drying) ${ }^{e}$ & [wt\%] & 90 & & \\
\hline Pyrolysis temperature ${ }^{a}$ & {$\left[{ }^{\circ} \mathrm{C}\right]$} & 500 & & \\
\hline Biocarbon temperature after cooling e & {$\left[{ }^{\circ} \mathrm{C}\right]$} & 50 & & \\
\hline HHV of the raw material, dry-based ${ }^{a}$ & {$[\mathrm{MJ} / \mathrm{kg} \mathrm{HHV}]$} & & 20.84 & $20.84 *)$ \\
\hline LHV of the raw material, dry-based ${ }^{a}$ & {$[\mathrm{MJ} / \mathrm{kg} \mathrm{LHV}]$} & & 19.65 & $\left.19.65^{*}\right)$ \\
\hline HHV of the biocarbon ${ }^{a}$ & {$[\mathrm{MJ} / \mathrm{kg} \mathrm{HHV}]$} & & 29.62 & $29.62 *)$ \\
\hline LHV of the biocarbon ${ }^{a}$ & {$[\mathrm{MJ} / \mathrm{kg} \mathrm{LHV}]$} & & 29.04 & $29.04 *$ \\
\hline $\begin{array}{l}\text { Heat loss in pyrolysis: Proportion of heat content of } \\
\text { produced pyrolysis gases (own use subtracted) } e\end{array}$ & [\%] & 2 & & \\
\hline $\begin{array}{l}\text { Total energy consumption in drying, including losses, as } \\
\text { steam }^{b}\end{array}$ & $\begin{array}{l}{[\mathrm{kWh} / \text { tonne }]} \\
\left.\mathrm{H}_{2} \mathrm{O}\right]\end{array}$ & 1100 & & \\
\hline Heat loss in drying ${ }^{b}$ & [\%] & 43 & & \\
\hline Heat loss in the steam boiler (radiation) ${ }^{e}$ & [\%] & 0.4 & & \\
\hline Excess air coefficient in burning e & & 0.001 & & \\
\hline Boiler blowdown e & [wt\%] & 4.0 & & \\
\hline Flue gas end temperature $e$ & {$\left[{ }^{\circ} \mathrm{C}\right]$} & 130 & & \\
\hline Steam pressure $e^{-}$ & {$[\mathrm{kPa}]$} & 200 & & \\
\hline Boiler approach $T^{e}$ & {$\left[{ }^{\circ} \mathrm{C}\right]$} & 9.77 & & \\
\hline $\begin{array}{l}\text { Correction factor for the enthalpy of vaporization for water, } \\
\text { at } 25^{\circ} \mathrm{C} \text {, per } 1 \text { wt\% of moisture }{ }^{c}\end{array}$ & {$[\mathrm{MJ} / \mathrm{kg}]$} & 0.0443 & & \\
\hline \multicolumn{5}{|c|}{ Calculated and applied feed stream compositions for reaction calculations: } \\
\hline Black pellets & [wt\%] & & 95.4 & \\
\hline Bark & [wt\%] & & & 95.4 \\
\hline Ash & [wt\%] & & 4.6 & 4.6 \\
\hline \multicolumn{5}{|l|}{ Fixed stoichiometry of the reactions: } \\
\hline Black pellets & [wt\%] & & -100 & \\
\hline Bark & [wt\%] & & & -100 \\
\hline $\mathrm{O}_{2}$ & [wt\%] & & -55.1 & \\
\hline$N_{2}$ & [wt\%] & & -0.01 & \\
\hline Biocarbon & {$[w t \%]$} & & 39.8 & 37.1 \\
\hline $\mathrm{CO}_{2}$ & [wt\%] & & 74.6 & \\
\hline $\mathrm{H}_{2} \mathrm{O}$ & {$[w t \%]$} & & 40.7 & \\
\hline $\mathrm{NO}_{2}$ & [wt\%] & & 0.00 & \\
\hline $\mathrm{SO}_{2}$ & [wt\%] & & 0.03 & \\
\hline Pyrolysis gas (artificial modelling component) & [wt\%] & & & 62.9 \\
\hline
\end{tabular}

Sources: ${ }^{a}$ Toloue Farrokh et al. (2019), ${ }^{b}$ Hannula \& Kurkela (2013), ${ }^{c}$ Alakangas et al., (2016), ${ }^{d}$ industry information within the study and ${ }^{e}$ estimated value.

*) The same heating values are assumed for $B a$ (bark) as for BP (black pellets) and biocarbon products. The bark dry content as received is an estimate.

\subsection{Economic analysis and assumptions}

To calculate the production costs, additional assumptions are required, as well as some calculation results from the process modelling. These are presented in Table 4.

The external energy requirements for drying, also needed for production costs estimations, are presented in the Table 7. 
Regarding labour differences, less operating labour and maintenance staff are required because of integration benefits and the existing staff in the pulp mill integrated bark scenario. Additionally, there is no need to handle raw materials, such as pellets, as opposed to the stand-alone black pellets scenario, where the raw material must be further transported to the pyrolysis plant. Pulp mill integrated bark scenario maintenance staff costs are assumed to be included in the capital expenditure (CAPEX) related maintenance costs (Table 5).

Estimation of the pulp mill's losses in the electricity generation, due to the utilization of steam in the drying of bark, is derived by customizing FUPU reference mill (Chapter 2.1).

Table 4. Assumptions made or resulting from process modelling, for the calculations of production costs estimations for scenario-specific biocarbon.

\begin{tabular}{|c|c|c|}
\hline & $\begin{array}{l}\text { Black } \\
\text { pellets } \\
\text { (BP) (1) }\end{array}$ & $\begin{array}{l}\text { Bark } \\
\text { (Ba) (2) }\end{array}$ \\
\hline \multicolumn{3}{|l|}{ Assumptions for biocarbon production costs estimation: } \\
\hline Process in operation $[\mathrm{h}]^{a}$ & 8,000 & 8,000 \\
\hline Degree of capacity utilization [\% ${ }^{a}$ & 100 & 100 \\
\hline Labour, total [person years] ${ }^{a}=$ & $27=$ & $16=$ \\
\hline Operating labour + & $15+$ & $10+$ \\
\hline Supervisory + & $5+$ & $5+$ \\
\hline Production engineer + & $1+$ & $1+$ \\
\hline Maintenance & 6 & 0 \\
\hline $\begin{array}{l}\text { Energy for drying raw material: as hot water [\%]/as low pressure } \\
\text { steam [\%] }\end{array}$ & N/A & $50 / 50$ \\
\hline Electricity generation yield: electricity/thermal load [\%] ${ }^{b}$ & 35 & N/A \\
\hline \multicolumn{3}{|l|}{ Key parameters resulting from process modelling: } \\
\hline Pyrolysis gases production yield, self-consumption subtracted [wt\%] & N/A & 57.3 \\
\hline LHV of pyrolysis gases $[\mathrm{MJ} / \mathrm{kg}]\left(500^{\circ} \mathrm{C}\right)$ & N/A & 12.5 \\
\hline $\begin{array}{l}\text { Internal energy for drying (as low pressure steam) from heat recovery: Proportion of } \\
\text { total energy consumption of drying [\%] }\end{array}$ & 100 & 4.7 \\
\hline Losses in electricity generation [kWh/tonne of steam] & $N / A$ & 110 \\
\hline $\begin{array}{l}\text { Estimated energy losses in the system: Proportion of the received raw material heat } \\
\text { load [\%] }{ }^{*} \text { ) }\end{array}$ & 5.1 & 1.9 \\
\hline $\begin{array}{l}\text { Excess heat load for electricity generation: Proportion of received raw material heat } \\
\text { load [\%] }\end{array}$ & 31 & N/A \\
\hline \multicolumn{3}{|c|}{$\begin{array}{l}\text { Sources: }{ }^{a} \text { Industrial expertise within the study and }{ }^{b} \text { general assumption. } \\
{ }^{*} \text { Derived from energy balances in Table } 7 \text {. In the scenario PB, if there would be a need for drying, also } \\
\text { the drying energy losses, covered by internal heat supply, would be included in the losses. In the scenario } \\
\text { Ba energy required for drying is analysed separately from the system, and the related losses in drying are } \\
\text { not considered in this figure. Also, losses in the burning of the produced pyrolysis gases (Ba) have not } \\
\text { been accounted for as they are outside the system boundaries. Burning takes place at the lime kiln. }\end{array}$} \\
\hline
\end{tabular}

In addition to the figures presented in Table 4, price estimations, logistics information and figures for estimating fixed costs are also required for the production costs calculations. These are listed in Table 5.

The selling price is fixed for all scenarios, taken as a representative average of biocarbon production costs in the different calculated scenarios (including other scenarios than those mentioned in this study). 
Fixed capital investment $(\mathrm{FCl})$ estimates are given in Table 5 for the required pyrolysis process and related sub-processes (e.g. drying, raw material handling). Black pellets conversion process is not included in the investment estimations, since black pellets are the feed raw material for the stand-alone black pellets scenario. The detailed cost breakdown as such is not available in public. To compare the derived $\mathrm{FCl}$ estimates a torrefaction plant study (Wilen et al., 2014) is used as a reference, estimating an investment of approx. €50 $\mathrm{M}$ (taken here as the TDC without the buildings) for a standalone torrefaction plant with an annual capacity of $200 \mathrm{k}$ tonne. In the pulp mill integrated bark scenario, in contrast to the stand-alone black pellets scenario, it is assumed there is no need for a raw material handling line as a bark handling line forms part of a pulp mill. Biocarbon must be pelletized before being transported to a steel/iron mill. A drying process is required for the pulp mill integrated bark scenario, but not for stand-alone black pellets scenario, where there is actually no real need for drying. The pyrolysis process requires higher temperatures than the torrefaction process. These differences are covered by the additional cost factor for TDC without buildings costs when compared to the torrefaction plant.

The buildings, other indirect costs and the contingency costs are estimated by proportions of the $\mathrm{FCl}$, based on Peters et al. (2002) within the given limits. Applied values are listed in Table 5. A working capital share of $5 \%$ of $\mathrm{FCl}$ (corresponding to a value of $5.3 \%$ of $\mathrm{TCl}$ ) has been obtained based on the value used by Humbird et al. (2011). Higher working capital shares are also proposed in the literature, for example, Peters et al. (2002) suggest a value of $15 \%$ of TCl for multi-purpose plants or major extensions to existing facilities. Start-up costs (learning rate, discounts, etc.) and staff training costs, for example, have not been included in the $\mathrm{TCl}$ at this stage.

The investment estimate for the pulp mill integrated bark scenario is much higher, 2.18 times the stand-alone black pellets scenario. This is due to the higher production capacity, being 2.17 times of the capacity for the stand-alone black pellets scenario The scaling factor effect is diminished due to the higher additional cost factor given for the pulp mill integrated bark scenario as compared with the stand-alone black pellets scenario. 
Table 5. Price estimations, logistics information, fixed-cost figures and total capital investment estimation for the scenarios for the calculation of production costs estimations for scenario-specific biocarbon.

\begin{tabular}{|c|c|c|c|}
\hline & $\begin{array}{l}\text { Reference: } \\
\text { Torrefaction } \\
\text { plant }\end{array}$ & $\begin{array}{l}\text { Black } \\
\text { pellets } \\
(\mathrm{BP})(1)\end{array}$ & $\begin{array}{l}\text { Bark } \\
\text { (Ba) (2) }\end{array}$ \\
\hline \multicolumn{4}{|l|}{ Total capital investment (TCI) estimation for the scenarios: ${ }^{a}$} \\
\hline Capacity - torrefied wood or biocarbon [k tonnes/a] & $200^{a}$ & 44.2 & 96.0 \\
\hline Scaling exponent ${ }^{b}$ & & 0.7 & 0.7 \\
\hline Additional costs factor of pyrolysis plant vs. torrefaction plant & & 1.03 & 1.31 \\
\hline \multicolumn{4}{|l|}{ TDC without buildings ${ }^{c}$} \\
\hline TDC without buildings [M€] $\left(76 \%\right.$ of $\left.F C I^{d}\right)$ & $50.0^{a}$ & $17.9^{a}$ & $39.2^{\mathrm{a}}$ \\
\hline Buildings (including services) [M€] (5\% of $\mathrm{FCl}^{d}$ ) & 3.3 & 1.2 & 2.6 \\
\hline$=T D C$ (total installed direct costs) [M€] & 53.3 & 19.1 & 41.8 \\
\hline Other indirect costs $[\mathrm{M} €]\left(12 \%\right.$ of $\left.F \mathrm{Cl}^{d}\right)$ & 7.9 & 2.8 & 6.2 \\
\hline Contingencies $[\mathrm{M} €]\left(7 \%\right.$ of $\left.F C I^{d}\right)$ & 4.5 & 1.6 & 3.5 \\
\hline$=F C l$ (Fixed capital investment) [M€] & 65.6 & 23.5 & 51.4 \\
\hline \multicolumn{4}{|l|}{ Land is excluded } \\
\hline Working capital [M€] (5\% of $\left.\mathrm{TCl}^{e}\right)$ & 3.5 & 1.2 & 2.7 \\
\hline$=\mathrm{TCl}$ (Total capital investment) [M€] & 69.1 & 24.8 & 54.1 \\
\hline \multicolumn{4}{|l|}{ Assumptions for biocarbon production costs estimates: } \\
\hline \multicolumn{2}{|l|}{ Biocarbon sales price estimate: $330+10 \%$ margin [€/tonne] ${ }^{f}$} & 363 & 363 \\
\hline \multicolumn{2}{|l|}{ Electricity: Purchase and sales price $[€ / M W h]^{f}$} & 35 & 35 \\
\hline \multicolumn{2}{|l|}{$\begin{array}{l}\text { Raw material or biofuel price: Based on heating value } \\
\text { [€/MWh] }\end{array}$} & 20 & 20 \\
\hline \multicolumn{2}{|l|}{ Hot water cost for drying $[€ / M W h]^{b}$} & $\mathrm{~N} / \mathrm{A}$ & 0 \\
\hline \multicolumn{2}{|l|}{ Labour cost [€//person/month] ${ }^{b}$} & 4,400 & 4,400 \\
\hline \multicolumn{4}{|l|}{$\begin{array}{l}\text { Operating labour } 100 \% \text {, maintenance } 115 \% \text {, supervisory } 125 \% \text { and } \\
\text { production engineer } 150 \% \text { of the reference labour cost }\end{array}$} \\
\hline \multicolumn{2}{|l|}{ Maintenance $[\% \text { of } T C I]^{c}$} & 3 & 3 \\
\hline \multicolumn{2}{|l|}{ Includes maintenance staff [Yes /No] } & No & Yes \\
\hline \multicolumn{2}{|l|}{ Insurance $[\% \text { of } \mathrm{TCl}]^{c}$} & 2.5 & 2.5 \\
\hline \multicolumn{2}{|l|}{ Other costs [\% of sales] ${ }^{c}$} & 3 & 3 \\
\hline \multicolumn{4}{|l|}{ Transportation costs: } \\
\hline - $\quad$ Handling fee $[€ / \text { tonne }]^{c}$ & & 1 & 1 \\
\hline - $\quad$ Railway transportation [€/tonne $/ 100 \mathrm{~km}]^{\mathrm{C}}$ & & 3.5 & 3.5 \\
\hline $\begin{array}{l}\text { Transportation distance }[\mathrm{km}]^{f} \text { (in BP scenario raw } \\
\text { material and in Ba biocarbon) }\end{array}$ & & 275 & 275 \\
\hline Opportunity cost of capital [\%] ${ }^{b}$ & & 5.0 & 5.0 \\
\hline Investment period $[a]^{b}$ & & 15 & 15 \\
\hline
\end{tabular}

\section{Results}

\subsection{Technical evaluation}

The significant difference is the biocarbon production capacity of the pulp mill integrated bark scenario, which is more than twice that of the stand-alone black pellets scenario, despite the estimated lower biocarbon yield for bark. This difference 
is due to the large amount of bark directed to the pyrolysis and the necessary pyrolysis gas for firing a lime kiln, respectively. Energy balances reveal that black pellets require almost no drying energy prior to the pyrolysis, with a moisture content close to $10 \mathrm{wt} \%$, which was set as the maximum value for the raw material moisture content requirement. Whereas, bark with a $60 \mathrm{wt} \%$ moisture content requires drying. The calculated energy balances follow the capacity, explaining the much higher thermal power figures of the pulp mill integrated bark scenario. Another important difference in the pulp mill integrated bark scenario is the use of hot water and steam for drying purposes from the pulp mill, without utilizing excess of pyrolysis gases internally.

Material balances for the scenarios are presented in Table 6. The amount of bark received is based on the volume of bark assumed to be available at the pulp mill. The need for air for burning (feed) and flue gases (output) is significantly lower for the pulp mill integrated bark scenario. This is because in this scenario only a small proportion of pyrolysis gases are burned to cover the endothermic reactions of pyrolysis and the major proportion are directed for further use in the lime kiln, while in the stand-alone black pellets scenario, all pyrolysis gases are burned within the system limits in order to produce electricity.

Table 6. Material balances resulting from the modelling.

\begin{tabular}{rcc}
\hline & $\begin{array}{c}\text { Black } \\
\text { pellets } \\
\text { (BP) (1) } \\
\text { [k tonne/a] }\end{array}$ & $\begin{array}{c}\text { Bark } \\
\text { (Ba) (2) } \\
\text { [k tonne/a] }\end{array}$ \\
\hline $\begin{array}{r}\text { FEED: } \\
\text { Raw material, as received }\end{array}$ & 116 & \\
Air for burning & 273 & 600 \\
SUM (FEED): & $\mathbf{3 8 8}$ & 131 \\
OUTPUTS: & & $\mathbf{7 3 0}$ \\
Biocarbon (at 50 ${ }^{\circ}$ C) & 44.2 & 96.0 \\
Pyrolysis gases & Burned & 137 \\
Flue gases & 344 & 164 \\
Vapour from drying & 0.52 & 333 \\
SUM (OUTPUTS): & $\mathbf{3 8 8}$ & $\mathbf{7 3 0}$ \\
\hline
\end{tabular}

Energy balances based on HHV are presented in detail in Table 7. Balas simulation software uses HHV values and provides energy-related data in this form. The pulp mill integrated bark scenario losses are higher mainly due to the drying requirements, which can be seen in the vapour losses and in other losses.

The simplified energy balances based on LHV used in production costs estimates are derived from an HHV-based energy balances. In the LHV energy balance for the pulp mill integrated bark scenario, the thermal load received by the system (feed), that is the thermal effect of raw material feed gaining in drying, is evaluated. The estimation is based on the moisture content change in the raw material, based on the formula from Alakangas et al. (2016). The drying/preheating energy required and their sources, covering also the losses, are analysed separately in the Table 7. 
The applied external as well as internal energy in drying and the related losses are outside the system boundaries of an LHV- based energy balance. Thus, the losses appear smaller for the pulp mill integrated bark scenario than for the stand-alone black pellets scenario, which is not the case. The drying losses for the pulp mill integrated bark scenario are covered by energy provided for drying (54.5 MW). From this ca. $43 \%$ are losses (23.4 MW). On the other hand, black pellets in the stand-alone scenario do not require further drying, and the related losses are negligible. In the pulp mill integrated bark scenario, $50 \%$ of the energy is assumed to be covered by hot water from the pulp mill. The remainder is covered by steam, primarily using internally generated steam, with the remaining steam sourced from the pulp mill.

Table 7. Energy balances resulting from the modelling. Expressed as higher heating values (columns to the left), in accordance with the applied Balas simulation software and as simplified energy balances derived as lower heating values (columns to the right).

\begin{tabular}{|c|c|c|c|c|}
\hline & \multicolumn{2}{|c|}{$\begin{array}{l}\text { HHV based } \\
\text { [MW HHV] }\end{array}$} & \multicolumn{2}{|c|}{$\begin{array}{c}\text { LHV based, simplified } \\
{[\mathrm{MW} \text { LHV] }}\end{array}$} \\
\hline & $\begin{array}{l}\text { Black pellets } \\
\text { (BP) (1) }\end{array}$ & $\begin{array}{c}\text { Bark } \\
(\mathrm{Ba})(2)\end{array}$ & $\begin{array}{l}\text { Black pellets } \\
\text { (BP) (1) }\end{array}$ & $\begin{array}{c}\text { Bark } \\
\text { (Ba) (2) }\end{array}$ \\
\hline \multicolumn{5}{|l|}{ FEED: } \\
\hline Raw material, as received & 75.2 & 175 & 69.8 & 133 \\
\hline Drying/preheating, losses included & 0.97 & 54.5 & & \\
\hline Thermal load received by the system (drying) & & & internal & 28.3 \\
\hline Air for burning & 0.24 & 0.12 & & \\
\hline SUM (FEED): & 76.4 & 229 & 69.8 & 161 \\
\hline \multicolumn{5}{|l|}{ OUTPUTS: } \\
\hline Biocarbon (at $50^{\circ} \mathrm{C}$ ) & 45.5 & 97.8 & 44.6 & 96.7 \\
\hline Pyrolysis gases & $\mathrm{N} / \mathrm{A}$ & 67.9 & N/A & 59.6 \\
\hline Internal energy for drying/preheating (steam) & 0.97 & 2.54 & & \\
\hline System excess energy used for drying (steam) & & & internal & $2.54 *)$ \\
\hline System excess energy (steam) & 21.7 & - & 21.7 & - \\
\hline Flue gas losses $\left(130^{\circ} \mathrm{C}\right)$ & 6.27 & 2.89 & & \\
\hline Vapour losses from drying & 0.05 & 31.1 & & \\
\hline Cooling losses of biocarbon & 1.09 & 2.35 & & \\
\hline Other losses & 0.79 & 24.9 & & \\
\hline \multicolumn{5}{|l|}{ (pyrolysis, boiler section, drying) } \\
\hline Losses (simplified, LHV based) & & & 3.5 & $\left.2.48^{* *}\right)$ \\
\hline SUM (OUTPUTS): & 76.4 & 229 & 69.8 & 161 \\
\hline \multicolumn{5}{|c|}{ DRYING/PREHEATING ENERGY DIVISION, LOSSES INCLUDED: ${ }^{* * *}$} \\
\hline External energy (hot water) & & & - & 27.2 \\
\hline External energy ( steam) & & & - & 24.7 \\
\hline Internal energy (steam) & & & 0.97 & 2.54 \\
\hline SUM (DRYING/PREHEATING ENERGY): & & & 0.97 & 54.5 \\
\hline \multicolumn{5}{|c|}{$\begin{array}{l}\left.{ }^{*}\right) \text { In the pulp mill integrated bark scenario energy required for drying is analysed separately from the } \\
\text { system. The excess energy used for drying covers also the drying energy losses (1.1 MW). } \\
{ }^{* *)} \text { The losses in drying are not considered in this figure. See above. } \\
\text { values are essential for the calculation of production costs scenarios. }\end{array}$} \\
\hline
\end{tabular}




\subsection{Pulp mill integration results}

In the pulp mill integrated bark scenario, all bark from the pulp mill is carbonized into biocarbon, whereas in the reference pulp mill, one half of the bark is burned in the boiler and other half is gasified to provide syngas for the lime kiln. Using steam to dry bark causes a reduction in electricity generation of approx. $36 \mathrm{GWh} / \mathrm{a}$. Furthermore, if bark taken from the boiler is not replaced by other bio-combustibles, the reduction is approximately $245 \mathrm{GWh} / \mathrm{a}$. For the production costs evaluation, it is assumed that a multi-fuel boiler is available at the site and the reduction in bark is compensated by using additional biofuels in the boiler. The cost of this fuel is assumed to correspond to the cost of bark. Furthermore, if a greenfield mill is considered, a significantly smaller boiler may be an option if bark carbonization technology is chosen instead of combustion technology. The hot pyrolysis gases are assumed to be sufficient to cover the syngas need of the lime kiln in the reference pulp mill. The energetic value of the bark is not converted into electricity but into biocarbon. The effect of biocarbon production on the energy balance of the market pulp mill is approx. a $4 \%$ reduction in net electricity output of the mill and a further reduction of approximately $25 \%$ if the bark used for pyrolysis is not replaced by other bio-combustibles. These results are visualized in Figure 4.

The obtained integration effects were further used in calculations of the biocarbon production costs for the pulp mill integrated bark scenario. The reduction in electricity generation, as well as the reduced need of bio-combustibles in the lime kiln were allocated on the biocarbon production costs.

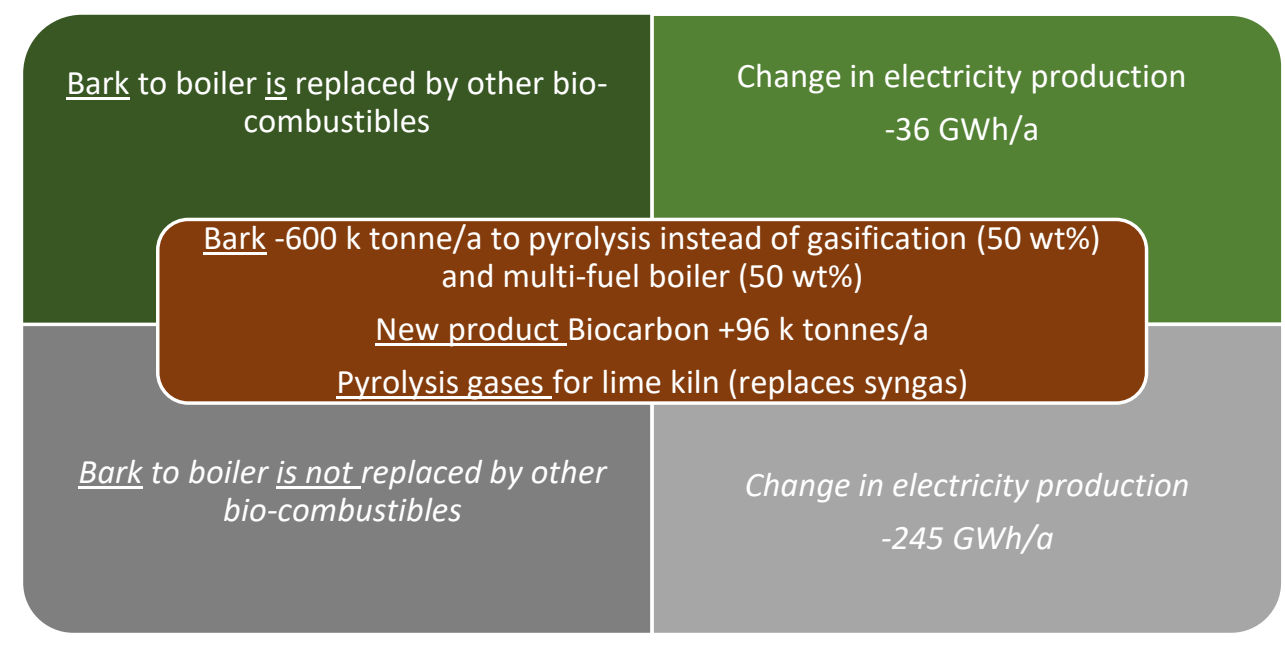

Figure 4. Effects of pulp mill integrated bark scenario when compared to the reference situation.

\subsection{Economic results}

The production costs estimate for the stand-alone black pellets scenario is $€ 367 /$ tonne of biocarbon, also taking into account the utilization of excess steam for electricity generation (Figure 5). A major proportion of the costs is raw material cost, black pellets, valued according to the heating value ( $20 € / \mathrm{MWh}$, Table 5). Black pellets are competing with other solid biofuels, setting the limit for the price. Still, it can be 
expected, that the price for black pellets would be somewhat higher than for bark for example, due to possibility of straightforward substitution e.g. with coal in the coal fired power plants. It can be estimated, that if the real price of black pellets is more than the applied value, ca. $70 \%$ of this price difference goes into the biocarbon production costs. For example, if the black pellets price would be $25 € / \mathrm{MWh}, 70 \%$ of this $5 € / M W h$ difference in the black pellets price would appear in biocarbon production costs, thus raising these costs by $3.5 €$ /tonne.

Production costs estimations for the pulp mill integrated bark scenario is $€ 257 /$ tonne of biocarbon (Figure 6). The raw material cost, bark, is also the predominant cost factor in this scenario, despite the lower valuation when compared to the stand-alone black pellets scenario, due to the moisture content of the received bark. Additional savings are achieved by the utilization of hot pyrolysis gases as fuel for the lime kiln. Labour costs are higher due to the higher production capacity when compared to the stand-alone black pellets scenario. Logistics costs are lower, less than one half compared to the stand-alone black pellets scenario. This is due to transporting biocarbon instead of the raw material, which is the case in the stand-alone black pellets scenario. Cost component production losses only apply to the pulp mill integrated bark scenario and refers to the reduction in net electricity output of the mill's power plant. The bark taken from the power plant for biocarbon production (50 wt\% of the total bark) is assumed to be compensated by using additional biofuels. Further, it is assumed that additional biofuel costs are at the same level as bark in terms of heat delivered and have therefore been neglected.

\section{BP -Black pellets at $10 \%$ moisture, transported to production site $(275 \mathrm{~km}) / € 367 /$ tonne}

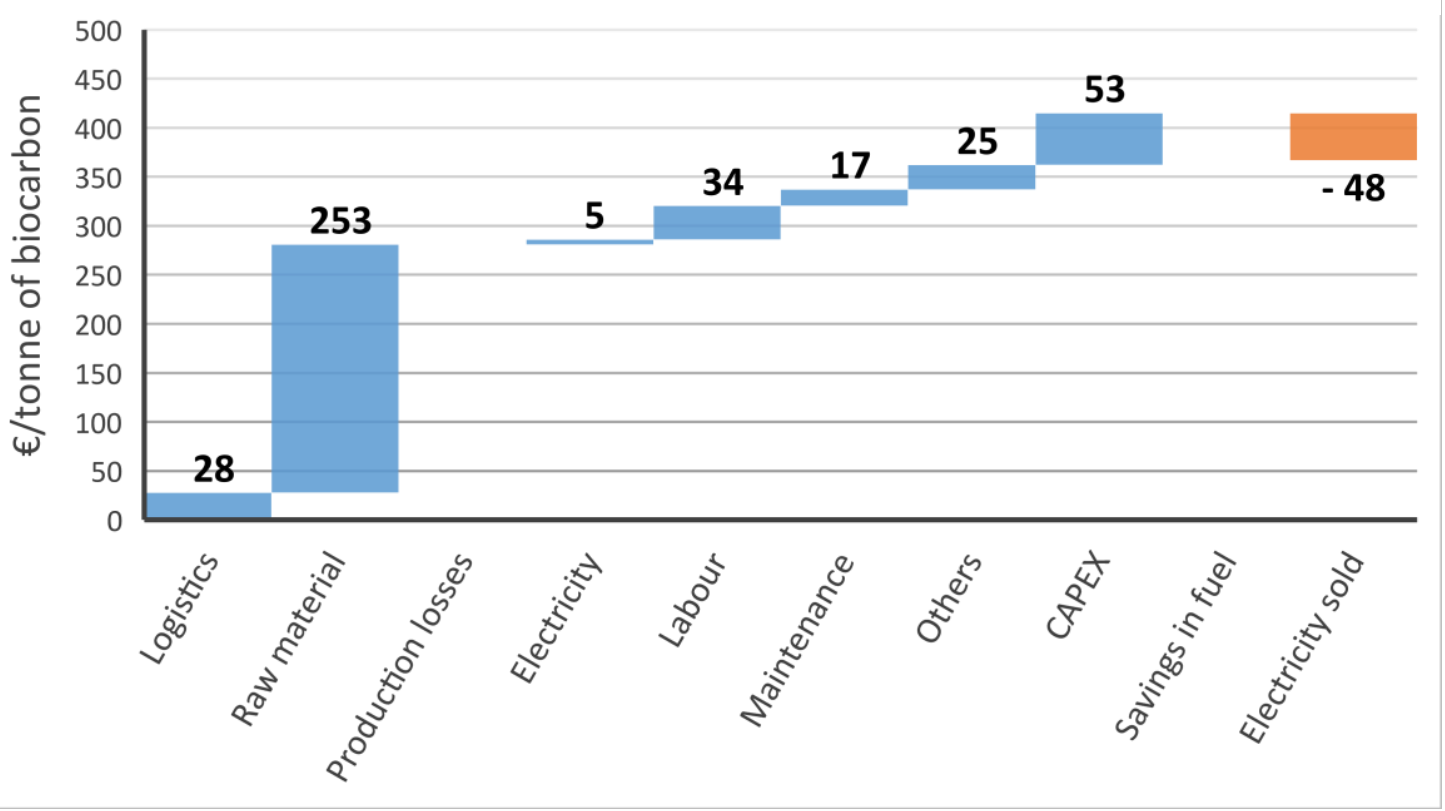

Figure 5. Production costs structure for the stand-alone black pellets scenario. 


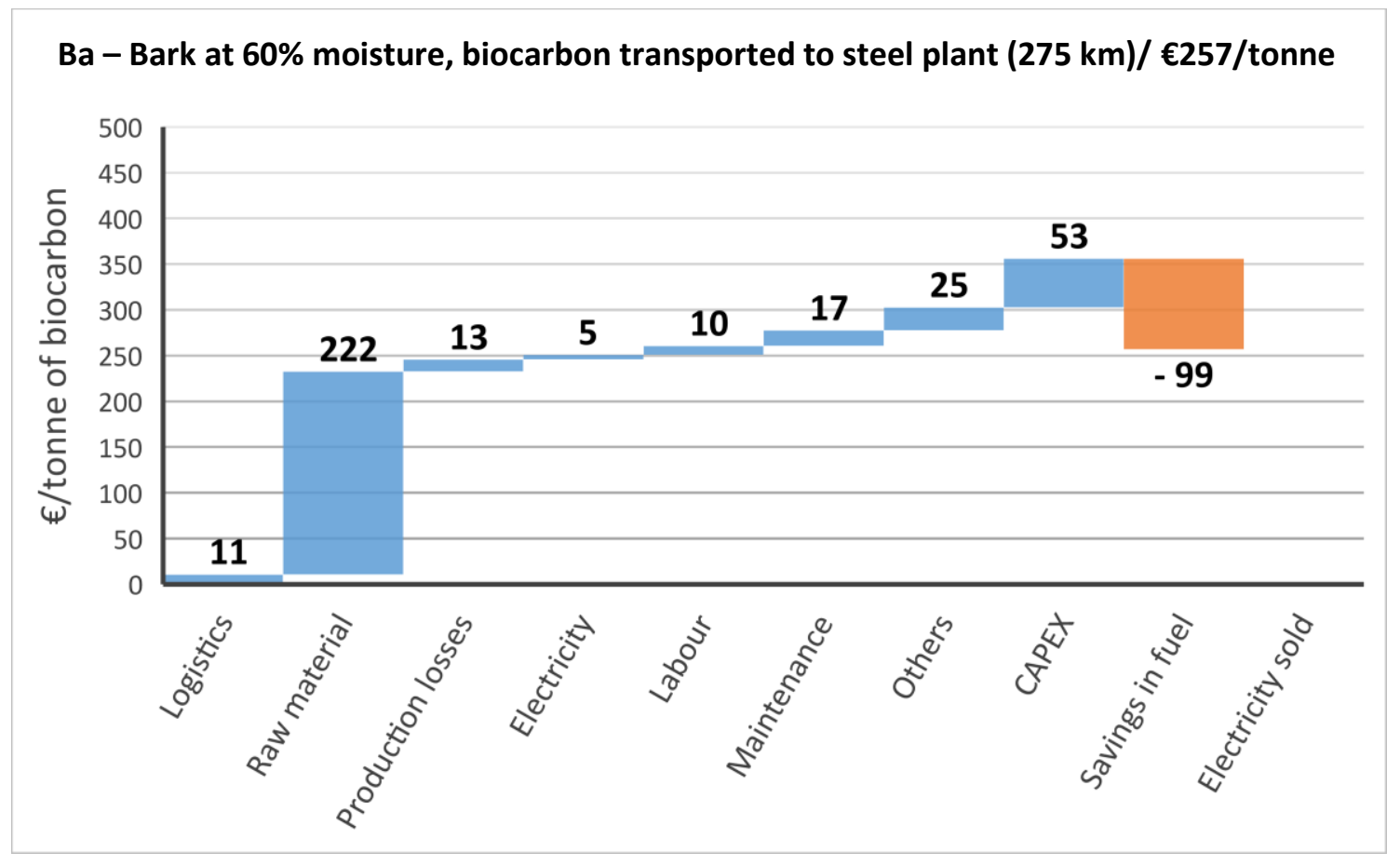

Figure 6. Production costs structure for the pulp mill integrated bark scenario.

\subsection{Sensitivity analysis}

A triangle for distribution was applied to the input parameters. The parameters are listed in Table 8. The baseline values in Figure 7 are based on the given distributions and not on the static values directly per se. The sensitivity of production costs to key cost factors is illustrated in Figure 7 . The selected parameters as key cost factors are listed in Table 8. Raw material prices are the most predominant factor. The cost of electricity is more predominant for the stand-alone black pellets scenario than the pulp mill integrated bark scenario. This is because in the stand-alone black pellets scenario, excess pyrolysis gases are burned in order to produce electricity. The transportation distance significantly affects transportation costs. In addition, the transported matter, raw material or biocarbon product, influences transportation costs due to the yield and related specific tonnages. In the stand-alone black pellets scenario, the raw material is transported, while in the pulp mill integrated bark scenario biocarbon product requires transportation. 
Table 8. Varied parameters for the respective scenarios' sensitivity analyses. Triangle distribution for input parameters was assumed. The @Risk tool was used in the sensitivity analyses.

\begin{tabular}{|c|c|c|c|}
\hline Parameter varied & MIN & STATIC & MAX \\
\hline Raw material price [€/MWh] & 15.0 & 20.0 & 25.0 \\
\hline Cost of electricity [€/MWh] & 35.0 & 35.0 & 68.0 \\
\hline Bark moisture content [wt\%] & $55.0 \%$ & $60.0 \%$ & $65.0 \%$ \\
\hline Black pellets moisture content [wt\%] & $10.0 \%$ & $10.4 \%$ & $10.8 \%$ \\
\hline Biocarbon yield - bark [wt\%] $\left.{ }^{*}\right)$ & $37.0 \%$ & $40.0 \%$ & $43.0 \%$ \\
\hline Biocarbon yield - black pellets [wt\%] $\left.{ }^{*}\right)$ & $40.6 \%$ & $43.6 \%$ & $46.6 \%$ \\
\hline Raw material as dry - bark feed [tonne/yr] $\left.{ }^{* *}\right)$ & 200,000 & 240,000 & 280,000 \\
\hline Raw material as dry-black pellets feed [tonne/yr] $\left.{ }^{* *}\right)$ & 86,544 & 103,853 & 121,162 \\
\hline $\begin{array}{r}\text { Transportation distance - biocarbon (bark) and black pellets } \\
\text { [km] }\end{array}$ & 100 & 275 & 450 \\
\hline$T C I-$ pulp mill integrated bark scenario $[M €]^{* * *)}$ & 37.9 & 54.1 & 70.3 \\
\hline $\mathrm{TCl}-$ stand-alone black pellets scenario $[\mathrm{M} €]^{* * *}$ & 17.3 & 24.7 & 32.1 \\
\hline
\end{tabular}

*) The yield change for black pellets (MAX-STATIC and STATIC-MIN) is fixed in the same way as for bark

$\left.{ }^{* *}\right)$ For black pellets and bark feed, the same relationships (MIN/STATIC and MAX/STATIC) are applied

$\left.{ }^{* * *}\right)$ The total capital investment minimum value is set to $70 \%$ of static and maximum to $130 \%$ of the static value 


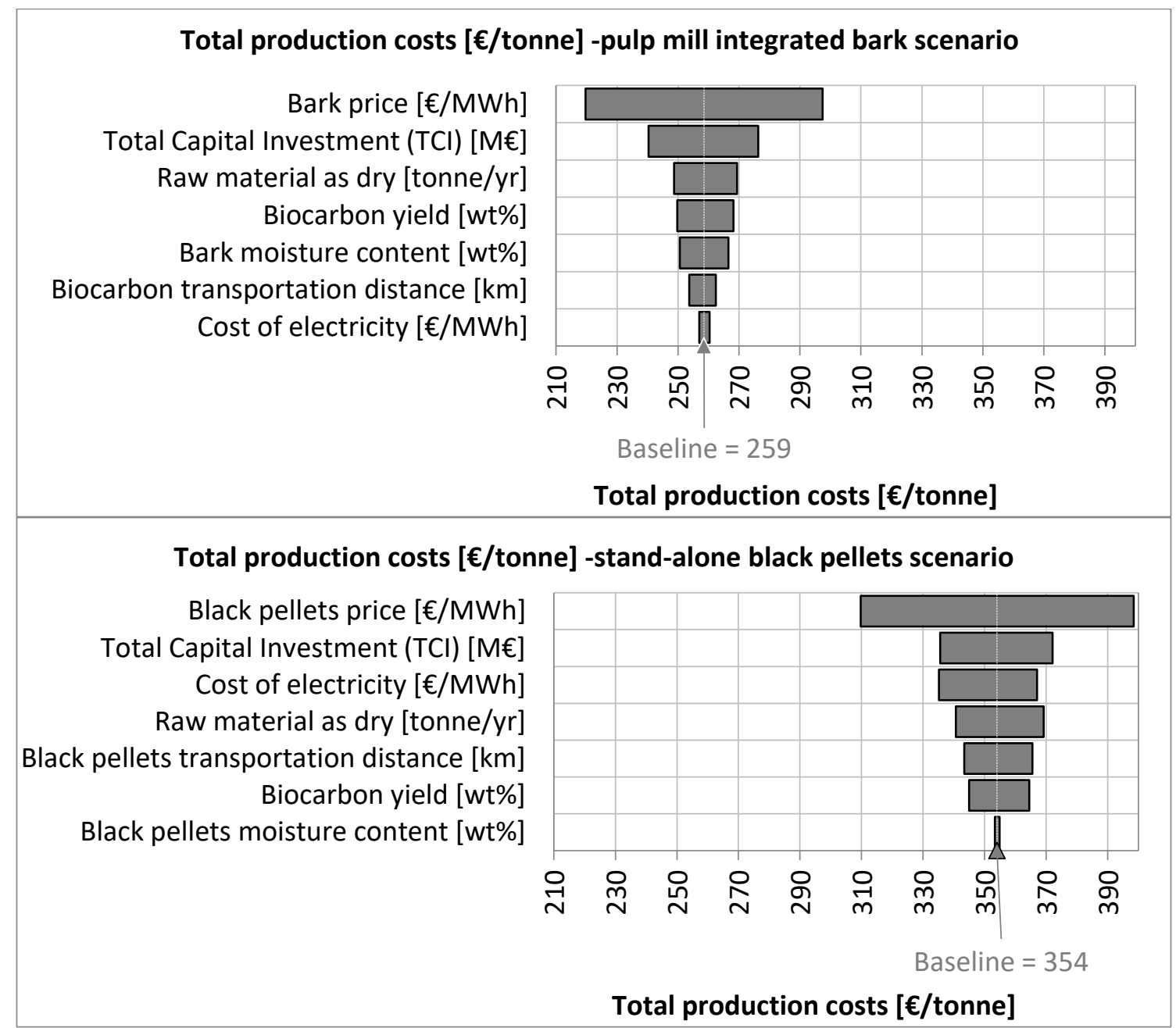

Figure 7. The sensitivity of biocarbon production costs to selected key cost factors. Inputs ranked by effect on output mean.

\section{Discussion}

With a high enough carbon to oxygen ratio, replacing $\mathrm{PCl}$ coal in the blast furnace injection with biocarbon produced by slow pyrolysis from softwood bark and from black pellets made of such bark has been found to be applicable. The current acceptable level for a $\mathrm{PCl}$ coal replacement ratio with biocarbon is $10-20 \mathrm{wt} \%$ while higher ratios will require further technological assessment of the detrimental elements affecting the blast furnace operation and solving certain technical limitations, such as sizing of $\mathrm{PCl}$ coal handling and pulverizing line, and re-designing the co-feed of coal and biocoal to the blast furnace. Physical and chemical properties must also be considered when designing the blast furnace biocarbon injection system. Similar assessments will be required for the usage of bio-based reductants in other respective smelting processes, e.g. in electric arc, plasma or submerged lance furnaces.

The cost of replacing coal and coke is a crucial factor for the success of new biocarbonbased process concepts. There are significant benefits for process integration to a pulp mill, particularly if pyrolysis gases can be utilized as fuel (e.g. lime kiln). The estimated 
production costs for a stand-alone plant were $\sim € 360 /$ tonne of biocarbon and the respective costs for an integrated process were $€ 260 /$ tonne of biocarbon. Previous studies indicate that the cost of bio-based reducers varies significantly based on the applied technology and quality of the bio-reducer (Suopajärvi 2018; 2014). When biocarbon is considered, the estimations are between $\sim € 220-510 /$ tonne. The realistic production costs obtained in this study for the integrated process in particular is close to the lower limit of these previous studies. The lowest estimate for production costs is for torrefied wood €110-180/tonne, which is yet not suitable for replacing $\mathrm{PCl}$ coal in the blast furnace injection, having too low carbon to oxygen ratio, and the relatively low heating value may also hinder it's use as a substitute for $\mathrm{PCl}$ coal.

The rising costs of emission trading relating to fossil coal usage will provide an additional boost to biocarbon.

Black pellets conversion process from bark is assumed to locate in the vicinity of the pulp mill. Excess bark availability at the mill sets the limits for the black pellets production, for further utilization in the stand-alone production of biocarbon close to the steel mill. To reach the same biocarbon production capacity as in the more theoretical pulp mill integrated bark scenario, the excess bark from two pulp mills may be needed. Instead, in the pulp mill integrated bark scenario it is assumed possible to use all the bark available at the single modern pulp mill for biocarbon production, and still provide the energy for the lime kiln requirements.

Hakala et al. (2019) estimated the biocarbon potential from the side-streams of forest industry (after the in-house use of this sector) in Finland to be ca. $1.5 \mathrm{M}$ tonne/a. These industrial side streams include bark, saw dust and forest chips. The Finnish ISI sector is estimated to need around $2 \mathrm{M}$ tonnes/a of carbon (Suopajärvi et al., 2013; Hakala et al., 2019). To cope with such demand, the scattered sources of biomaterial is a challenge while hauling of the harvested woody material for longer distances will not be economically viable, as pointed out by Olofsson (2019). Supply sources large enough for the industrial scale of operation can yet be located locally within the forest industry, as typically a biorefinery, a bio-ethanol plant or one or more sawmills. These could provide the necessary side-stream biomass. Bark in the biorefinery, for example, could provide a substantial source of 40 to $90 \mathrm{k}$ tonnes as biocarbon. Still, it may not be realistic to assume that all the carbon required in the ISI sector in Finland could be provided as biocarbon, converted from industrial side streams and/or biomass, due to the competing uses.

If biocarbon, to be produced as in pulp mill integrated bark scenario presented in this article, is used as a substitute for fossil $\mathrm{PCl}$ coal, the estimated reduction of global warming potential in terms of $\mathrm{CO}_{2}$ equivalents is up to $86 \%$ - $95 \%$ for the substituted part. The reduction potential depends whether Finnish average grid electricity or green electricity is applied to cover the losses in electricity generation of the mill's power plant (Hakala et al., 2019). If CCS technologies would be coupled with the utilization of biocarbon at the steel mill, it will further lower the $\mathrm{CO}_{2}$ emissions caused in the steel production. 


\section{Conclusions}

Based on the estimated biocarbon production costs, converted from bark or from black pellets made of such bark, the pulp mill integrated bark scenario looks promising, providing a better economic option than stand-alone black pellets scenario, to be located close to the steel mill or respective metal making unit. By increasing the production rate of the stand-alone black pellets scenario and by heat and/or fuel gas integration with e.g. the steel mill, the production costs may be further reduced also for the stand-alone black pellets scenario.

There is still uncertainty in the actual achievable investment costs for the commercial units in the capacities in question and the pyrolysis units in this size range are yet to be commercially proven. However, such a process will provide an ample source - at an annual potential of up to 95,000 tonnes - of biocarbon. The benefits for the pulp mill integrated bark scenario are the possibility to burn hot pyrolysis gases in a lime kiln, replacing original fuels, and utilization of excess low temperature heat such as hot water and steam for biomass drying. Regarding future research, the techno-economic analysis conducted for the black pellet - bark case can equally be applied for other lignocellulosic residues. In connection with appropriate data of biomass availability and $\mathrm{CO}_{2}$ emission trading the methodology provides a basis for analysing concepts of voluminous biocarbon production from within the forest sector to end-users in metals production and processing.

\section{Acknowledgements}

The authors would like to thank the steering groups of the FOR\&MET and SYMMET $R \& D$ projects for their inputs and comments.

\section{Funding}

This work was supported by the Business Finland and conducted as a part of the FOR\&MET R\&D project (project no. 1608/31/2016) Added Value from Forest Industry for Metals Producing and Processing Integrates (2016-2019), as well as a part of the SYMMET R\&D project (project no. 4286/31/2018) Symbiosis of metals production and nature (2018-2020).

\section{References}

1. Ahonen, I., 2019. Fossiilisen hiilen korvaaminen biohiilellä onnistui SSAB:n testissä Raahessa - tulevaisuudessa jopa 20 prosenttia hiilestä voisi korvautua biohiilellä. Kaleva news. August 7, 2019. Available at: https://www.kaleva.fi/uutiset/pohjoissuomi/fossiilisen-hiilen-korvaaminen-biohiilella-onnistui-ssabn-testissa-raahessatulevaisuudessa-jopa-20-prosenttia-hiilesta-voisi-korvautua-biohiilella/824748/

2. Alakangas, E., Hurskainen, M., Laatikainen-Luntama, J., Korhonen, J., 2016.

Properties of indigenous fuels in Finland. VTT Technology 272. VTT Technical Research Centre of Finland Ltd.

3. Antal, M. J., Grønli, M., 2003. The Art, Science, and Technology of Charcoal Production ${ }^{\dagger}$, Industrial \& Engineering Chemistry Research. 
4. Arasto, A., 2015. Techno-economic evaluation of significant $\mathrm{CO}_{2}$ emission reductions in the iron and steel industry with CCS. Dissertation. VTT Science 111.

5. Bioenergy International, 2019. SSAB Brahestad successfully concludes blast furnace biocoal tests. August 14, 2019. Available at:

https://bioenergyinternational.com/pellets-solid-fuels/ssab-brahestad-successfullytested-to-replace-fossil-carbon-with-bio-carbon

6. Bioenergy International, 2018. SSAB powering up for fossil-free steel production. Bioenergy International. February 1, 2018.

7. Channiwala, S., Parikh, P., 2002. A unified correlation for estimating HHV of solid, liquid and gaseous fuels. Fuel 81 (8), 1051-1063.

8. Fernandez-Pales, A., Levi, P., 2019. Industry - Tracking Clean Energy Process. International Energy Agency IEA. Last updated May 24, 2019. Available at: https://www.iea.org/tcep/industry/

9. Hakala, J., Kangas, P., Penttilä, K., Alarotu, M., Björnström, M., Koukkari, P., 2019. Replacing Coal Used in Steelmaking with Biocarbon from Forest Industry Side Streams. VTT Technology 351. VTT Technical Research Centre of Finland Ltd.

10. Hannula, I., Kurkela, E., 2013. Liquid transportation fuels via large-scale fluidisedbed gasification of lignocellulosic biomass. VTT Technology 91. VTT Technical Research Centre of Finland Ltd.

11. Humbird, D., Davis, R., Tao, L., Kinchin, C., Hsu, D., Aden, A. 2011. Process Design and Economics for Biochemical Conversion of Lignocellulosic Biomass to Ethanol Process Design and Economics for Biochemical Conversion of Lignocellulosic Biomass to Ethanol. Technical Report NREL/TP-5100-47764.

12. HYBRIT, 2019. Three HYBRIT pilot projects - towards fossil free iron and steel. Available at: http://www.hybritdevelopment.com/articles/three-hybrit-pilot-projects

13. ICE, 2020. EUA Futures. Available at: https://www.theice.com/products/197/EUAFutures/data?marketld=6434094\&span=1

14. Ifu Hamburg., 2015. e-Sankey 3.2. Available at: https://www.ifu.com/en/

15. Kangas, P., Kaijaluoto, S., Määttänen, M., 2014. Evaluation of future pulp mill concepts - Reference model of a modern Nordic Kraft pulp mill, Nordic Pulp and Paper Research Journal 29(4), pp. 620-634.

16. Kuparinen, K., Vakkilainen, E. 2017. Green Pulp Mill: Renewable Alternatives to Fossil Fuels in Lime Kiln Operations. BioResources 12(2), pp. 4031-4048.

17. Mason, W., 1926. Process and apparatus for disintegration of wood and the like. United States patent 1578609.

18. Mousa E., Wang C., Riesbeck J., Larsson, M., 2016. Biomass applications in iron and steel industry: An overview of challenges and opportunities. Renewable and Sustainable Energy Reviews 65, 1247-1266. 
19. Ng, K. W., Giroux, L., Todoschuk, T., 2018. Value-in-use of biocarbon fuel for direct injection in blast furnace ironmaking. Ironmaking and Steelmaking 45, 406-411.

20. Olofsson, E., 2019. Regional effects of a green steel industry - fuel substitution and feedstock competition. Scandinavian Journal of Forest Research 34(1), 39-52.

21. Outotec., 2017. HSC Chemistry 9. Available at:

https://www.outotec.com/products/digital-solutions/hsc-chemistry/

22. Palisade Corp., 2015. @Risk. Risk Analysis Add-in for Microsoft Excel. Version 7.0.1., Professional Edition Build 396.

23. Peters, M., Timmerhaus, K., West, R. 2002. Plant Design and Economics for Chemical Engineers. McGraw-Hill Education, Fifth edition.

24. Riva, L., Nielsen, H.K., Skreiberg, Ø., Wang, L., Bartocci, P., Barbanera, M., Bidini, G., Fantozzi, F., 2019. Analysis of optimal temperature, pressure and binder quantity for the production of biocarbon pellet to be used as a substitute for coke. Applied Energy 256(113933).

25. Sherrard, A., 2019. Nel to supply electrolyzers for HYBRIT fossil-free steel pilot plant. Bioenergy International. April 25, 2019. Available at:

https://bioenergyinternational.com/technology-suppliers/nel-to-supply-electrolyzersfor-hybrit-fossil-free-steel-pilot-plant

26. Statistics Finland, 2018. 001 - Kotimaisten polttoaineiden käyttäjähinnat energiantuotannossa (ei sis. alv:a). StatFin Database. Updated 12 September, 2018. In Finnish only. Available at: https://www.stat.fi/tup/statfin/index.html

27. Suopajärvi, H., 2014. Bioreducer use in blast furnace ironmaking in Finland: technoeconomic assessment and $\mathrm{CO}_{2}$ emission reduction potential. Dissertation. University of Oulu. Acta Universitatis Ouluensis, C Technica 513.

28. Suopajärvi, H., Umeki, K., Mousa, E., Hedayati, A., Romar, H., Kemppainen, A., Wang, C., Phounglamcheik, A., Tuomikoski, S., Norberg, N., Andefors, A., Öhman, M., Lassi, U., Fabritius, T., 2018. Use of biomass in integrated steelmaking - Status quo, future needs and comparison to other low-CO2 steel production technologies. Applied Energy 213, 384-407.

29. Suopajärvi, H., Kemppainen, A., Haapakangas, J., Fabritius, T. 2017. Extensive review of the opportunities to use biomass-based fuels in iron and steelmaking processes. Journal of Cleaner Production 148, 709-734.

30. Suopajärvi, H., Pongrácz, E., Fabritius, T., 2013. The potential of using biomass based reducing agents in the blast furnace: A review of thermochemical conversion technologies and assessments related to sustainability. Renewable and Sustainable Energy Reviews 25, 511-528.

31. Toloue Farrokh, N., Sulasalmi, P., Fabritius T., 2019. Added value for forest industry for metals producing and processing integrates (FOR\&MET): Project report of University of Oulu. University of Oulu, Process Metallurgy Research Unit. http://urn.fi/urn:isbn:9789526222073 
32. Tutturen, K., 2013. Industrial charcoal production with power generation at Mully Children's Family Yatta, Kenya. Master's Thesis, Norwegian University of Life Sciences.

33. Valmet, 2019. BioTrac - the path to a fossil-free future. Available at:

https://www.valmet.com/media/articles/biofuels-and-biomaterials/biotrac-the-pathto-a-fossil-free-future/

34. Valmet, 2016. Wingems. Available at:

http://www.valmet.com/products/automation/solutions-for-pulp-and-paper/apcadvanced-process-controls/valmet-wingems/

35. VTT Technical Research Centre of Finland, 2013. BALAS Process Simulation Software. Available at: http://balas.vtt.fi/

36. Wiklund, C., 2016. Optimization of a steel plant utilizing converted biomass.

Dissertation. Åbo Akademi University. ISBN 978-952-12-3398-2.

37. Wilen, C., Sipilä, K., Tuomi, S., Hiltunen, I., Lindfors, C., Sipilä, E., Saarenpää, T-L., Raiko, M., 2014. Wood torrefaction - market prospects and integration with the forest and energy industry. VTT Technology 163. VTT Technical Research Centre of Finland. 